\title{
The Voice from Above
}

\author{
By StePHan Guth and Minaila YoRdanova
}

Things certainly do not look rosy in Tunisia, and even 10-11-year old Zaynab in Zaynab takrah al-thalj / Zaineb n'aime pas la neige (Zeineb Hates the Snow), a documentary about emigration [ 7 Migration], is tired of having to sing, every morning at school, the 'meaningless' national anthem and cheer so much "Tunisie, Tunisie!" Yet, the forced patriotism of the morning muster, preserved at Tunisian schools as a ritual even five years after the Revolution, seems to be nothing more than a faint remnant of the omnipresent hegemonic official discourse of earlier times - times when the ancient regime was still in place, and times also that are still very well remembered and the memory of which is consciously kept alive in assessments of the despotic past, like 'Alà hallat 'ayni / ’̀ peine j'ouvre les yeux (As I Open My Eyes), as a warning for the present and future [ $\lambda$ Past vs. Present]. Now, however, and thanks to the Revolution and a belief, shared by most, that information in contemporary Tunisia should no longer be monopolized by the state, the voice of a 'Big Brother,' so present before the Revolution, has disappeared almost completely. Announcements made by the new government are constantly relativized by information from other channels and deconstructed by a watchful opposition and an ever-growing civil society, and there is lively public discussion of any step taken, or words uttered, by those in power. When, for instance, President Beji Caid Essebsi makes an attempt to stage himself as an heir of the almost uncontested 'father,' Habib Bourguiba, his recourse to positively-laden imagery is immediately debunked as a weak politician's helpless attempt to gain broad popular support - a ridiculous move that social media activists just seem to have been waiting for to make fun of [ $\lambda F$ Father Figures, $\lambda$ Social Media]. The times when the heroic self-staging of the President would have become the official narrative definitely belong to the past.

Not at all so in Egypt-which, with all probability, is the reason why translations of Orwell's 1984 are still among the year's best-sellers (ORWELL). And this is also why the 'Voice from Above' - the official narrative of the state of affairs in the country, broadcast on radio and TV and spread in newspapers as well as on the Internet - forms part of any critical assessment of the present, be it documentary or dressed in fiction. When Tāmir al-Sa ${ }^{c} \overline{1} d$ portrays 'his' Cairo [ 7 Downtown/Centre-ville] on the eve of the Revolution (Ākhir ayyām al-madina / In the Last Days of the City), he depicts it as a space filled with official radio and TV programs hailing the President's latest achievements. Of course, this is Mubārak's voice, not Sīsī's - but has this changed substantially? [ $\nearrow$ Past vs. Present, $\nearrow$ Present $=$ Past (Stuck)]. Obviously, it still does make sense also for the authors of Nawwāra, Mawlānā, and The Nile Hilton Incident to recall conditions as they were under Mubārak or the intermediate SCAF government: When the housemaid Nawwāra commutes between her home in a Cairo slum and the luxurious gated community where she works [ $\lambda^{c} A s h w \bar{a}^{3} i y y \bar{a} t$, $\lambda$ Gated Communities / Compounds], the SCAF's statements and promises come over the radio on the bus, the microbus, or the $\lambda$ Tuk-tuk; when the petty policeman Nūr al-Dīn in The Nile Hilton Incident returns home and opens his shabby black-and-white TV, there is nothing but official propaganda: Mubārak having achieved yet another success, Mubārak opening yet 
another new chapter in Egypt's glorious history, Mubārak steadfastly facing all challenges, Mubārak providing for his beloved "children," and so on; and the producers of Mawlänā do not only show, in similar scenes, that the "Voice from Above' is everywhere, permeating public as well as private space, but they also take us to one of the studios that contribute to producing this voice, granting us insight into the information politics of the regime and the fear of those responsible of touching upon sensitive issues or perhaps even criticizing the ruler. Compared to such settings, the present situation as portrayed in assessments of the more recent state of affairs does not seem to be much different: successes of the Sīsī government are heralded also from the taxi driver's or hairdresser's radios in the short feature film Hiarrr jäff șayfan (Dry Hot Summers), and the radio's voice proclaiming newly created job opportunities or important initiatives taken to improve the educational system fills also the place in the slum where Nādiya and her children are struggling hard to survive (Abadan lam nakun atfālan / We Have Never Been Kids).

However, proclamations of successes and state-decreed optimism are not the only tones in which the 'Voice from Above' speaks to the people. And it does not remain unchallenged either, although this is certainly more difficult and dangerous in Egypt than it is in Tunisia. The Voice comes in many different forms, an Orwellian creature with a modern twist, argues journalist 'Amr Khalifa. It is a combination of criminalizing independent writing and somehow managing to pass off "the true crime of state propaganda" as journalism, all in the name of "brainwashing a fatigued and willing public" (KHALIFA). The author describes the Voice's modus operandi as a mixture of repression and recruitment, the carrot and the stick of Egypt's propaganda machine. The trend, he claims, started in the 1950s with Nasser employing army officers as in-house censors in all major media outlets. And it has continued ever since [ $\lambda$ Past vs. Present, $\lambda$ Present $=$ Past $($ Stuck $)]$. Through a combination of silencing the voice of dissent and defining a clear message to be delivered by charismatic state-supporting popular personalities, the Sisi regime has always been eager, and to a large extent successful in its efforts, to make sure that its voice is the only one people at large really listen to. For Khalifa, the public dialogue has turned into an endless monologue. "Without an alternative narrative, Egyptians will continue to be the clay in the government's moulding hands, watching TV as the days pass by," concludes the piece, evoking stark dystopian images [ $\nearrow$ The Voice from Above].

The journalist's impression is telling in itself. But it is also not the full picture. Generally speaking, on the surface many things can be said - and are in fact being said quite frankly. Thus, many contributions in the thick end-of-the-year review of the semi-official magazine al-Musawwar talk openly about food shortages [ $\nearrow$ Baby Milk], the economic crisis [ $\lambda$ Dollar Crisis, $\lambda T$ Tourist Resorts] and inflation, and many other shortcomings or drawbacks, such as deplorable hygiene and poor medical services in hospitals, or the underdevelopment of the provinces [ $\lambda$ Center vs. Periphery], or the fact that "the State does not have a comprehensive plan to appreciate the youth's creative potential," as a professor of engineering and energy has it in one of the review's many interviews with experts in their respective fields (al-Mușawwar, 106); even the difficulties that the security apparatus has in coping with terrorism (or what is declared as such) are not taboo or denied, nor are social fragmentation, the collapse of national unity, and the waning sense of patriotism—all in all a rather gloomy picture. 
Yet, addressing such issues is only one thing. There should also be deep and critical analysis - which, however, is mostly lacking from these reports. And those whom they blame for the shortcomings and drawbacks - if they blame someone at all-are never those in power, but at best a collective and very general "we". And this is also why "we"-not those in power- "have to work hard in order to compensate for five years of chaos" (ibid., 144). The regime itself favours yet another variant. It does not deny obvious shortages, failures, difficulties, crises either - after all, nobody should say that it ignores facts or tries to sweep problems under the carpet; rather, it is eager to show that it is well aware of that all and takes up the challenges with determination (muwäjaha, "facing," is a keyword not only at the Cairo Bookfair where "Culture is fi 'l-muwäjaha," i.e., courageously facing all kinds of challenges). But when it comes to explaining what has gone wrong, it does not blame "us", but the numerous enemies of Egypt, whether external or internal [ $\nearrow$ The Suspect Foreigner, $\lambda$ True $=$ False $($ Life in Limbo)], those

enviers (al-hāsidūn) and evil people (ahl al-sharr) [who] dislike the fact that we are close to realizing our hopes. Therefore, they do everything to throw us in the pits and force us to pluck the blossoms before the plant can bear fruits (ibid., 51).

Many public persons echo this narrative. When, for instance, Harb al-Dahshūrī, a former president of the National Football Association, is asked about the many defeats Egypt has suffered this year, he answers that one of the main reasons is that Egypt these days is "exposed to the biggest defamation campaign (hamlat tashwīh) in its history" (ibid., 204), blaming foreign and native elements who allegedly seek to distort the country's picture in the media and abroad and in this way sow pessimism and despair in people's hearts.

Therefore, and although the problems are undeniable, one should not let the "forces of the evil" gain the upper hand [ $\nearrow$ Inferiority vs. Superiority]. Rather, one should turn one's attention to the many successes that have been achieved so far and give good reason to be optimistic: giant development projects like the Serapeion culvert (saḥ̂āra) that brings Nile water to Sinai and will turn thousands of feddāns into agricultural lands, are already bringing progress to every corner of Egypt [ $\lambda$ Center vs. Periphery], and "the building of the country continues" (as the Minister of Planning assures us); the huge investments put in the new administrative Capital ("Sisity") promise to generate "extraordinary revenues"; the modernisation of the Armed Forces is advancing, enabling "the best soldiers on Earth" to continue to proudly fulfil their meritorious duties and protect the dear beloved homeland's well-being (salāma); the Stock Exchange is on the best way to "rejuvenation" (inti 'âsh); the World Health Organisation has congratulated Egypt on its successful fight against all kinds of diseases and viruses; the dream of complete self-sufficiency in food "can definitely come true," one can be "very optimistic for Egypt's future" - even when it comes to getting a grip on the problem of widespread sexual harassment: towards the end of the year, Māyā Mursī, the president of the National Council for Women is proud to state that "the girls [in our country] have raised the slogan 'I'll report harassment to the police station"' and that, taken together with the proclaimed success of several official campaigns encouraging and supporting all kinds of women's initiatives, there even seems to be good reason to think bigger now: "Leadership positions are waiting for us," she declares (ibid., 166-7) [ オMale vs. Female].

jais • 21 (2021) - Themed Section In2016: *285-*290 
And one should of course also remember that the most characteristic trait of the "Egyptian personality" is its "unbreakable will" anyway (ibid., 140) - a quick look into history [ 7 Past vs. Present] suffices to show that Egypt has seen many crises but always been able to rise again and that Egyptians are masters of the "art of turning trials into benefits" (fann tahwi l al-mihnna ilà minha) (ibid., 160) [ $\lambda$ Normality = Heroism (Surviving)]. Given that "our people does not know brokenheartedness" and "our will is bigger than any trial" (as for example Hānī Ramzī̄, the former captain of the Egyptian national football team, thinksibid., 206 [ \Football]), it should be a matter of course and of honour to follow al-Sīsī's and others' appeals to "rise" and "stand shoulder to shoulder (takātuf)" to "bear the burden," "endure" and "face the great challenges" (as 'Ișām 'Abd al-Mun im, another former football association president, formulates the recipe for the makhraj, the "way out" of the crisisibid., 207). "Yes, Egypt can!" (ibid., 114), especially so because it is guided by President alSīsi, the leader in whom one can trust because this man is capable of helping the country up after it has stumbled ('athara); "under al-Sisi's rule, Egypt will never break/collapse (tankasir)" (ibid., 104). So, do not believe the "enviers," defamers, slanderers, and other "forces of the Evil" who only work

to deprive the people of their trust in their Leader who has chosen them. [...] one has to stand up against weak belief. If you do not resist, He [the Leader] may not choose you again, and then the hands of the clock will go back to where they were before the herald of a good future [lit., the glad tidings, good omens, propitious signs: al-bishāra] had arrived. (Ibid., 51)

All-pervasive as this type of official narrative is, many believe in it and echo it faithfully. But there are also many attempts to disclose its logic as deceitful. Mostly these operate via juxtaposition. When the voice from above is heard heralding glorious successes in Abadan lam nakun atfālan, Nawwāra, or Ākhir ayyām al-madīna, the spectators see Nādiya toiling to scrub the floor around the cramped toilet in her slum flat, or Nawwāra's minibus crossing a densely crowded, dusty and loud megalopolis with striking class differences [ $\nearrow$ Affluence vs. Destitution], or a shabby old city centre with rotten elevators, decaying flats, a lot of beggars, and obtrusively roaring mosque loudspeakers [ $\nearrow$ Downtown/Centre-ville]. Satire uses similar techniques. The opening page of Islām Gāwīsh's il-Waraqa 2 shows a man (= the average Egyptian) sitting on the back of a motorcycle, driven at high speed by a woman in black (= Egypt), looking determined to drive on. With fear speaking from his face, the man asks, "Where are you taking us, Egypt?" And Mme Egypt only answers, "Yalla, just on with it!" (GĀWĪSH, 5). The ridiculing effet of many satirical Youtube channels, too, builds on the evident contrast, say: contradiction, between an obvious frightening, dangerous, and not at all hope- or trust-inspiring reality and the optimism of the voice from above [ $\nearrow$ Hope vs. Hell, $\nearrow$ Hope = Hell (Dystopia), オInferiority = Superiority (Satire)]

Having a long experience of controlling the press, radio and TV, it is not really difficult for the regime to contain critical voices uttered in these media. The main challenge for it to ensure the hegemony of the official discourse today, however, is probably $\nearrow$ Social Media. Yet, although it is hard, it is not impossible either - with the help of "digital armies," as journalist 'Amr Khalifa calls the state's digital anti-"subversion" forces. According to Khalīfa, the use of these "armies" spans back to the days of Mubārak, and it has expanded

jais 21 (2021) - Themed Section In2016: *285-*290 
particularly after 2015. An online row, however, brings these online groups into the spotlight once again. In November, Khālid Rif'at, a professor at Suez Canal University and "a supporter of the regime," publishes screenshots of posts from the closed Facebook group "Union of the Supporters of the State,", after being himself attacked by the digital soldiers. The pictures appear to show the members of the group, allegedly run by the journalist Ibrāhīm al-Garhịi, strategizing over how best to promote different state policies through attacking critics of the regime, spreading rumours and expressing their explicit support, while warning each other not to post identical content to avoid being accused of taking organized actions (al-HINDİ; 'ALĪ).

The new information is soon picked up by a number of Arabic media outlets outside of Egypt, leaving many wondering about the depth and breadth of the state's online propaganda activities. Some speculate about the cost of maintaining an online army ('ALĪ), others look for evidence of coordination between the social media trolls and online news sites, most notably Youm 7 (al-HINDİ). But the mechanisms of operating the apparatus are also of interest. Reports emerge on the thousands of profiles ('ALİ), a mixture of public figures, fake accounts and private individuals who constantly engage in monitoring online activity, harassing the opposition, spreading false information and influencing public opinion. Regardless of the facts behind the accusations, one thing is clear. The fear of the ever-open eyes and mouth of the administration is very real.

Not least because the pro-Sisi journalist and social media users seem particularly good at defusing potential political tension by providing alternative narrative on controversial events. Al-Sisi sold the land? Not at all. It was just the first step in a greater plan to get Egypt out of the Camp David agreement and defeat Israel ('ALÄ' AL-DĩN) [ $\nearrow$ Red Sea Islands]. The downing of Metrojet Flight 9268, the murder of Giulio Regeni and the crash of Egyptian Air flight 804 - could the country have security issues? Think again! It is all part of a grand US and UK conspiracy, aimed at harming Egypt's international image and bringing the Muslim Brotherhood back to power (MEMRI). All pieces of the puzzle are constantly being rearranged to fit neatly into the official public discourse, the unified voice blasting loudly from radio transmitters, newspaper pages, TV screens and social media, blurring the line between reality and fiction and building a world of alternative facts [ $\lambda$ True vs. False, $\lambda$ True $=$ False (Life in Limbo) $]$.

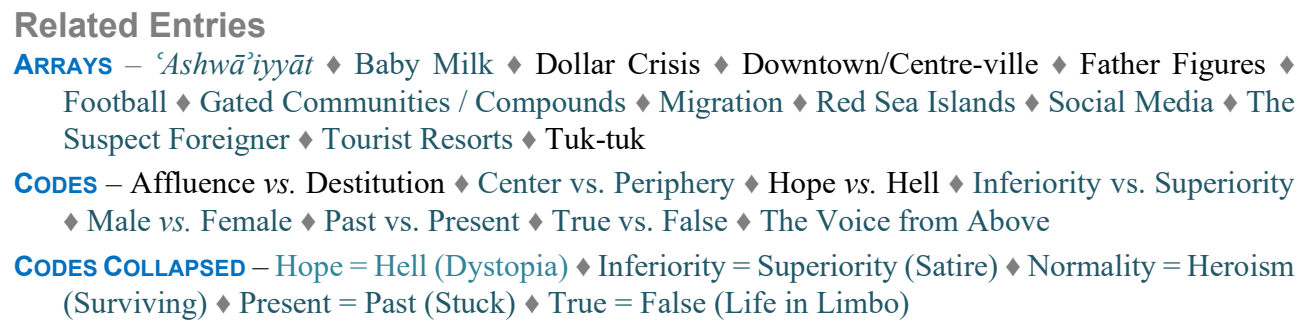

jais • 21 (2021) - Themed Section In2016: *285-*290 


\section{References}

\section{Written}

'ALĀ' AL-Dīn, Muhammad . 2016."Lijān al-Sīsī al-'iliktrūniyya: hayyā 'ilà 'l-kidhb.” UltraSawt, April

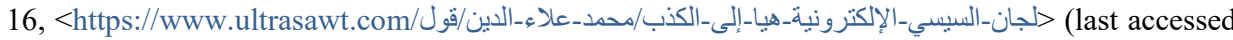
November 25, 2018).

'Alī, Tāmir. 2016. "Faḍīhat al-lijān al-'iliktrūniyya takshif taḍlīl al-Sīsī lil-Miṣriyyīn." 'Arabī21, فضيحة_اللجان_الإلكترونية_تكثف_تضليل_السيسي-2https:/arabi21.com/story/959429) >للمصريين (last accessed November 25, 2018).

GĀWīsh, Islām. 2016. il-Waraqa 2. Cairo: Dār Ṭūya.

al-Hindī, Ḥusām. 2016. "Suqūṭ 'ūlà katā’ib 'taqfîl al-internet': mādhā ta'rif 'an 'subūbat' al-lijān al'iliktrūniyya fĩ Mișr?" SāsāPost, November 7, <https://www.sasapost.com/ibrahim-elgarhi-andelectronic-committees/> (last accessed November 25, 2018).

Khalifa, Amr. 2016. "In Egypt, journalism is a crime.” Middle East Eye, December 2, 2016, rev. Dec. 6, <http://www.middleeasteye.net/columns/actually-egypt-journalism-crime-1337317191> (last accessed November 25, 2018).

[MEMRI =] The Middle East Media Research Institute. "Conspiracy Theories in Egypt Surrounding Crash of EgyptAir Flight 804: Accusations against U.S., U.K., Israel, Turkey; Claims of Western Plot against Egypt.” MEMRI, 6 June 2016, <https://www.memri.org/reports/conspiracy-theoriesegypt-surrounding-crash-egyptair-flight-804-accusations-against-us-uk $>$ (last accessed November 25, 2018)

[al-Muṣawwar =] N. N. "2017—_ām al-binā̄' al-șacb wa'l-mu’lim.” al-Muṣawwar, no. 4812 (special issue), December 28, 2016

[ORWELL =] ŪRwīl, Jūrj. 1984: riwāya / tarjamat Shafīq As'ad FARĪD. Cairo: Dār Āfāq, 2017 [C2016] - Earlier translations, like the one by Anwar al-SHĀMİ (al-Markaz al-Thaqāfĩ al-'Arabī, 2014) were still prominently on display in bookshops, at street vendors, or at the Bookfair.

Movies

Abadan lam nakun atfălan (We Have Never Been Kids). Documentary by Maḥmūd Sulaymān (Mahmood Soliman). EG, U.A.E., Qatar, RL 2016.

Ākhir ayyām al-madīna (In the Last Days of the City). By Tāmir al-Sacīd (Tamer el Said). EG, DE, UK, U.A.E. 2016.

'Alà hallat 'aynī / À peine j'ouvre les yeux (As I Open My Eyes). By Leyla Bouzid. TN, F, B 2015.

Hārr jäff șayfan (Dry Hot Summers). Short film by Sharīf al-Bandarī (Sherif Elbendary). EG, DE 2015 Mawlānā (Our Master) / The Preacher. By Magdī Aḥmad 'Alī (Magdy Ahmed Ali). EG, U.A.E. 2016.

Nawwāra (Nawara). By Hāla Khalīl (Hala Khalil). EG 2016.

The Nile Hilton Incident. By Ṭāriq Șālị̣ (Tarik Saleh). EG, DE, SE, DK 2017.

Zaynab takrah al-thalj / Zaineb n'aime pas la neige (Zeineb Hates the Snow). Documentary by Kawthar Bin Haniyya (Kaouther Ben Hania). TN, F, Qatar, RL, U.A.E. 2016.

stephan.guth@ikos.uio.no

\mly201@yahoo.co.uk 